\title{
Occurrence of beach debris in Tunda Island, Banten, Indonesia
}

\author{
Adinda_Maharani ${ }^{1,3}$, Noir $\mathrm{P}_{\text {Purba }}{ }^{2 *}$ and Ibnu Faizal $^{2}$ \\ ${ }^{1}$ Komitmen Research Group, Padjajaran University, Indonesia \\ ${ }^{2}$ Marine Research Laboratory (MEAL), Padjajaran University, Indonesia \\ ${ }^{3}$ HIMAIKA-FPIK, Padjajaran University, Indonesia \\ FPIK-UNPAD, Jl. Ir. Sukarno km. 21 West Java-INDONESIA \\ *Corresponding author, e-mail: noir.purba@unpad.ac.id
}

\begin{abstract}
Marine Debris is one of the spotlight issues of the world. The existence of marine debris can disrupt the ecosystem. Marine Debris carried by the current to coastal areas and accumulated along the coast. The study area of this research was on the coastline of TundaIsland, which located between Ban-ten and Lampung Provinces. These two provinces are part of two major islands of Indonesia, Java and Sumatra Island which have a high density of population. Household needs produce every day directly proportional to the population. This study is to record what types of garbage contained along the coast. There are 8 stations used in this study using International Coastal Cleanup (ICC) form with an area of $100 \mathrm{~m} 2$ collection at each station. From $800 \mathrm{~m} 2$ area coverage, 1,234 items collected with $47 \mathrm{~kg}$ weight of debris and the density $0.072 \mathrm{~kg} / \mathrm{m} 2$ with abundance 0.75 items $/ \mathrm{m} 2$. This result suggests that household needs give the big proportion of debris such as Food wrapper, cigarettes butts, and foam pieces. In addition, the study indicates that there is a strong relation between human activities and spreading of debris.
\end{abstract}

\section{INTRODUCTION}

Beaches located on smaall island in Indonesia are areas with different characteristics, requiring suistanable and integrated environmental management[1,2]. The biodiversity found in small islands is very diverse, but small islands are vulnerable to damage such as natural disasters or pollution. Limitations of garbage disposal areas, resulting in the processing of infrastructure on the small island is still lacking [3 ].

Marine litter is found in all oceans of the world, from the poles to the equator, and from continental coastlines to small islands. The geographical position will affect the presence of marine waste [4]. When many people move closer to the coast, will result in increased marine waste continuously [5].

The accumulation of plastic waste is a problem across the world's oceans, coastlines and marine ecosystems, because they have ecological and economic impacts as they can disrupt 
ecosystem stability and problems for marine animals and birds $[6,7,8]$ and reduce the value - environmental aesthetic values.

Marine debris is one issue that is in the spotlight in the world today because it causes a bad impact on the sea environment, social-economic and public health $[9,10]$. Marine Debris is a solid material produced or processed directly or indirectly, intentionally or unintentionally, disposed of or abandoned in the marine environment [11]. Marine debris is generally the result of anthropogenic (human) activity. The negative impact of marine waste is greatly felt by the neglected small islands [12,13].

The study of Marine Debris in Indonesia is important to develop Indonesia is the second largest contributor of waste in the world with a total waste of 3.2 million tons [4]. The increase of marine waste in the territorial ocean of Indonesia is very fast, to make a small island in the middle of the sea. $[14,15,16]$

The marine debris is sourced from the sea and the land produces a gradual buildup in the marine and coastal environments, which destroy the coast, float on the surface, float in the water column, and even found on the deep seafloor. Over the past five or six decades, seawater pollution and seawater contamination in the world, wider coastal waters and open oceans by plastics and other synthetic, non-biodegradable materials has become an everincreasing phenomenon [17,18].Some fractions of increased amounts of post-powder plastic waste must have escaped recycling and waste streams and made their way into the global ocean [19].

\section{METHODS}

\subsection{Site Description}

Tunda Island is a small island is located in Java Sea, in the northern of Banten Gulf. Administratively, the island is included in the district of Serang, Banten.Tunda Island is a vast island of about 300 acres. In 2007, the population reached 3,000 people Defer Island.Geographyc Located TundaIsland in 5 $48^{\prime} 43^{\prime \prime}$ LS dan $106^{\circ} 16^{\prime} 47^{\prime \prime}[20]$.Tunda Island actually already a very attractive tourism objects. The beauty of the beach and sea further yet unexplored.TundaIsland has three marine ecosystems. That are coral, seagrass and mangrove. Though sailing activities with a view of the sea and dolphins, fishing, snorkeling, diving, see the sunset and sunrise is an attractive tourist potential. Only a few investors investing or conducting business in the tourism industry in Tunda Island. So that local governments should continue to explore the potential of this exciting unspoiled[21].

\subsection{Data Collection}

There are 8 points around Tunda. The location is part of the island that is not submerged in sea water. Location was taken around the coastal area of Tunda Island. Each location represents the ecosystem and coastal characteristics of Tunda Island. 

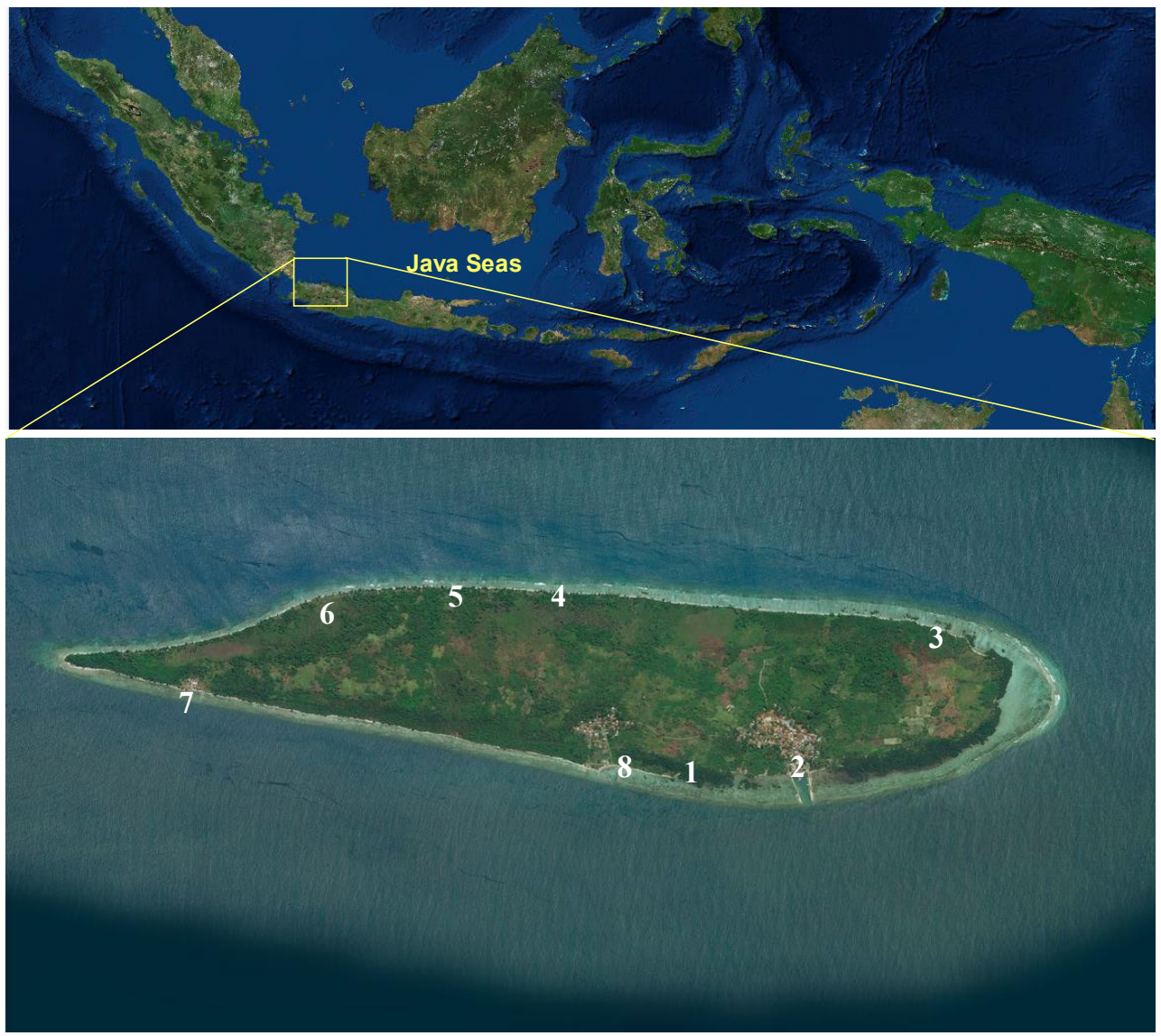

Fig1.Tunda Island Location and Stations Located

The method used in the collection of waste data in mangroves using the form of International Coastal Cleanup is downloaded from (http://www.oceanconservancy.org/ourwork/international-coastal-cleanup/dataform.pdf) for garbage collection. There are 4 contents in the form: garbage type, weight, location and width of garbage area. The width of the width area using a 100 meters long line of transects. Tools and materials used are garbage bags, GPS, roll meters. There are 6 categories of junk written in the form ie; A. most likely to find the goods, b. fishing gear, c. packaging materials, d. personal hygiene, e. other waste, $\mathrm{f}$. Small trash less than $2.5 \mathrm{~cm}$ ).

\section{RESULTS AND DISCUSSION}

Waste collection is picked up at 6 point stations in a mangrove forest. There are 6 categories of trash found based on the ICC form iecategoria) most likely to find items, b) fishing gear, c) packaging material, d) personal hygiene, e) other trash, f) tiny trash less than $2.5 \mathrm{~cm}$. However, there is one category of garbage found on the island of UntungJawa and not included in the form so that the addition of categories, namely g) clothes. Trash types most likely to find items are the most commonly found waste, as this type of garbage includes packs of ma-right packaging which are the basic needs of the general public for daily consumption. So this garbage will continue to be produced every day. The second 
category is fishing gear. Fishing gear is a tool waste fishing equipment used by the fishermen. Packaging Material is a type of waste packaging materials. The next category is personal hygiene; this garbage is a personal hygiene item. Tiny trash less than $2.5 \mathrm{~cm}$ is garbage that size less than $2.5 \mathrm{~cm}$ and in the form of small pieces of large garbage. The last category that is an additional unusual category category is Clothes, this garbage in the form of clothing or personal items (clothing, sandals, etc.).

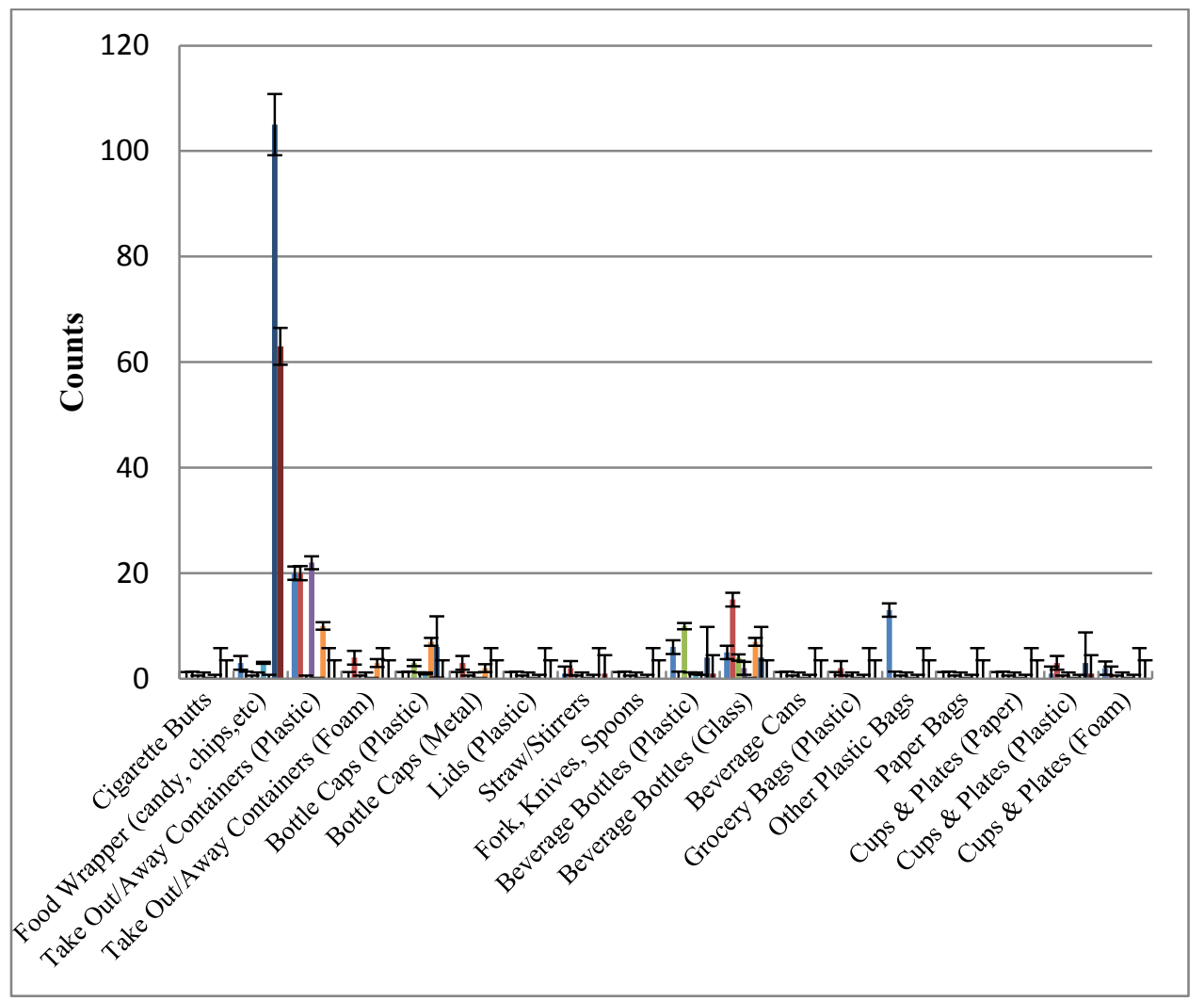

Fig 2. Most Likely To Find Items Chart

Figure 2 is a Most Likely To Find Items chart in 8 stations. This category of garbage includes waste that is commonly found in coastal areas. Household waste is most often consumed by people. that this type of garbage scattered at each point station. Of the 18 types of waste contained in this category, the most common type of waste is food wrapper with the total amount collected from all stations is 174 pieces. This garbage is mostly found in station 7, from 174 pieces 105 pieces are in station 7. Based on Figure 2 most frequently found waste is type A2 is Food wrapper. This garbage is often generated by the community or tourists while playing on the beach. The stalls incoastal area sell food with wrap so that the amount of waste is to be the most widely found. 


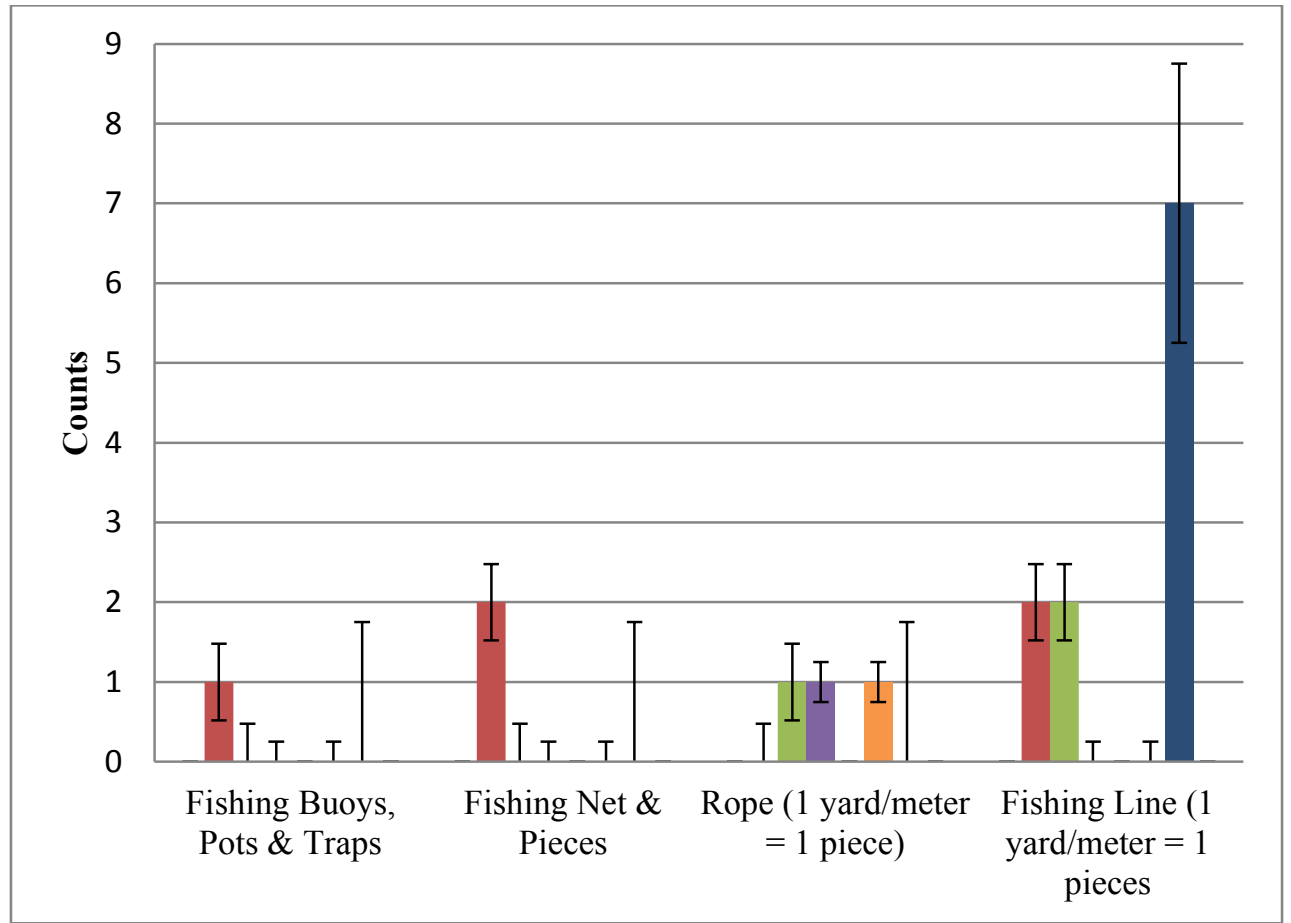

Fig 3. Fishing Gear Chart

Figure 3. shows the Fishing Gear category. This type is found in station 7 with total waste 7 pieces with a type of garbage Fishing line $(1$ yard/meter $=1$ piece $)$ or rope net +1 meter. Most found trash is Fishing Line, there are 12 pieces of garbage found from all stations. This garbage is produced from fishing equipment of fishermen dumped in the sea, or caught during fishing, then drifted and involved in the coast. Because of the shape of a mesh net and rope, make this garbage easily stuck in the mangrove or sand in coastal area. 


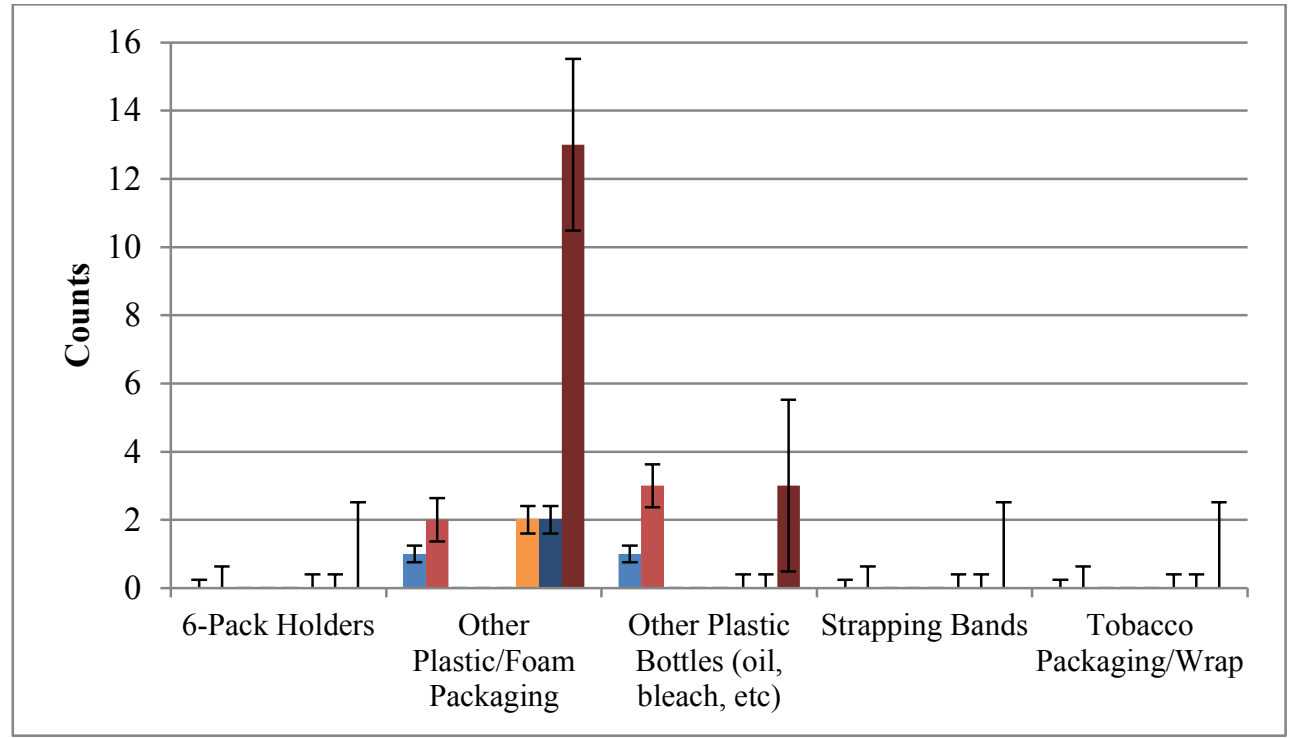

Fig 4. Packaging Material Chart

Figure 4. shows the Packaging Material Chartcategory chart. The most common type of waste from this category is Other plastic/foam packaging with the total number found in all stations is 20 pieces. Packaging Material category at most available at the station 8 . There are some small stalls owned by residents, so it can be analyzed Foam Packing is from small stalls selling packaged food packets.

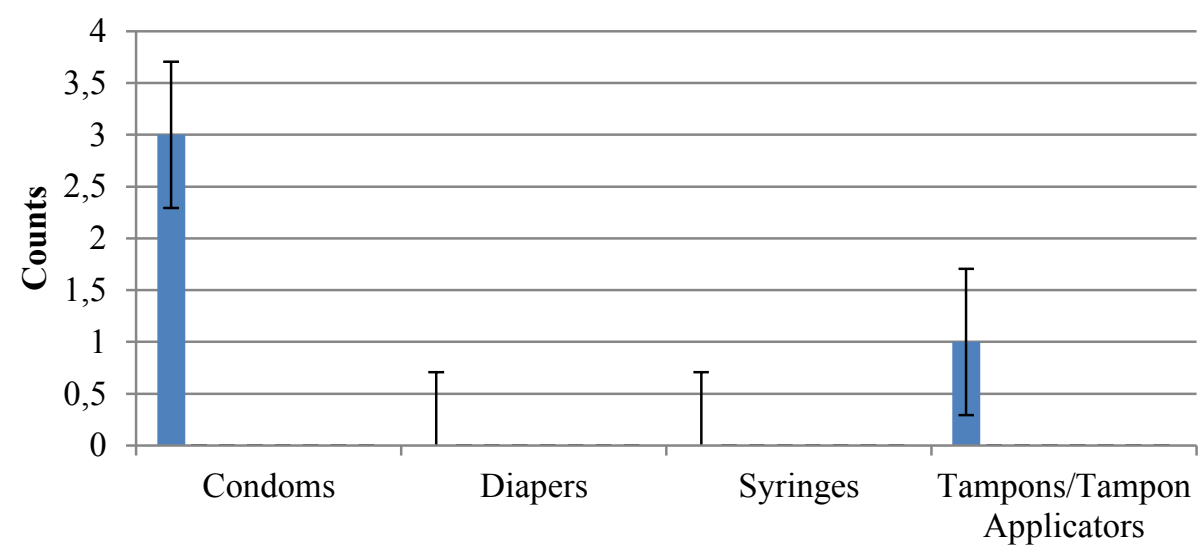

Fig 5. Personal Hygine Chart 
Figure 5. shows the personal hygiene category trash chart. The most widely found from this category is Condoms with the number of 3 pieces and only found in station 1 . Total waste of this category found in all stations only 4 pieces. Type of waste category of Personal Hygiene is indeed rarely found in the coast because the species is not commonly used by surrounding communities. In addition, this type of garbage is slightly dangerous and cannot be thrown away carelessly like needles and Tampon syringes.

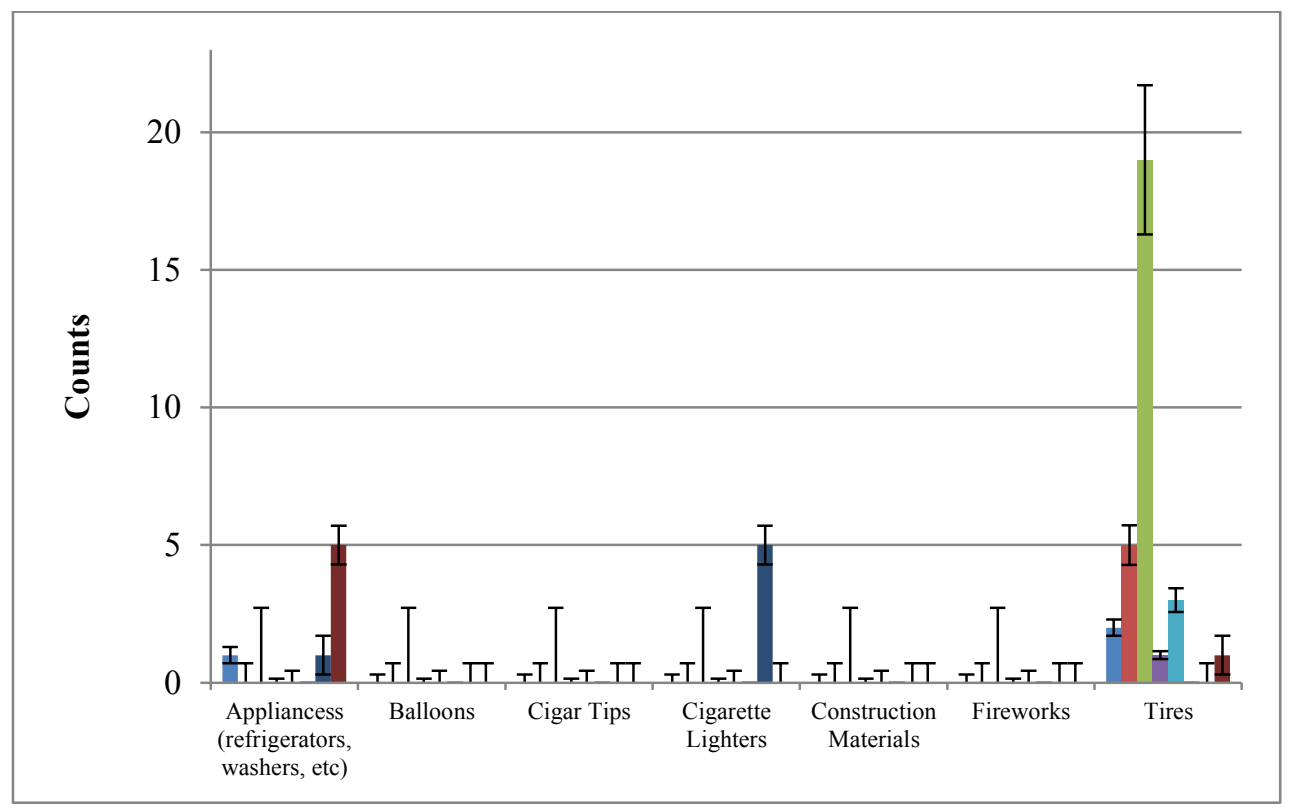

Fig6. Other Trash

Figure 6. shows the other trash category chart. The most common types of waste are tires with a total of 31 pieces. Tires most commonly found in station 3 with a total of 19 pieces. In addition to the often found garbage tires are balloons and matches. There is a little privilege in this type of garbage, the rare type of trash is type of trash or the equipment (refrigerator, washing machine, etc.). However, this waste is found in station 1 and 8 . 


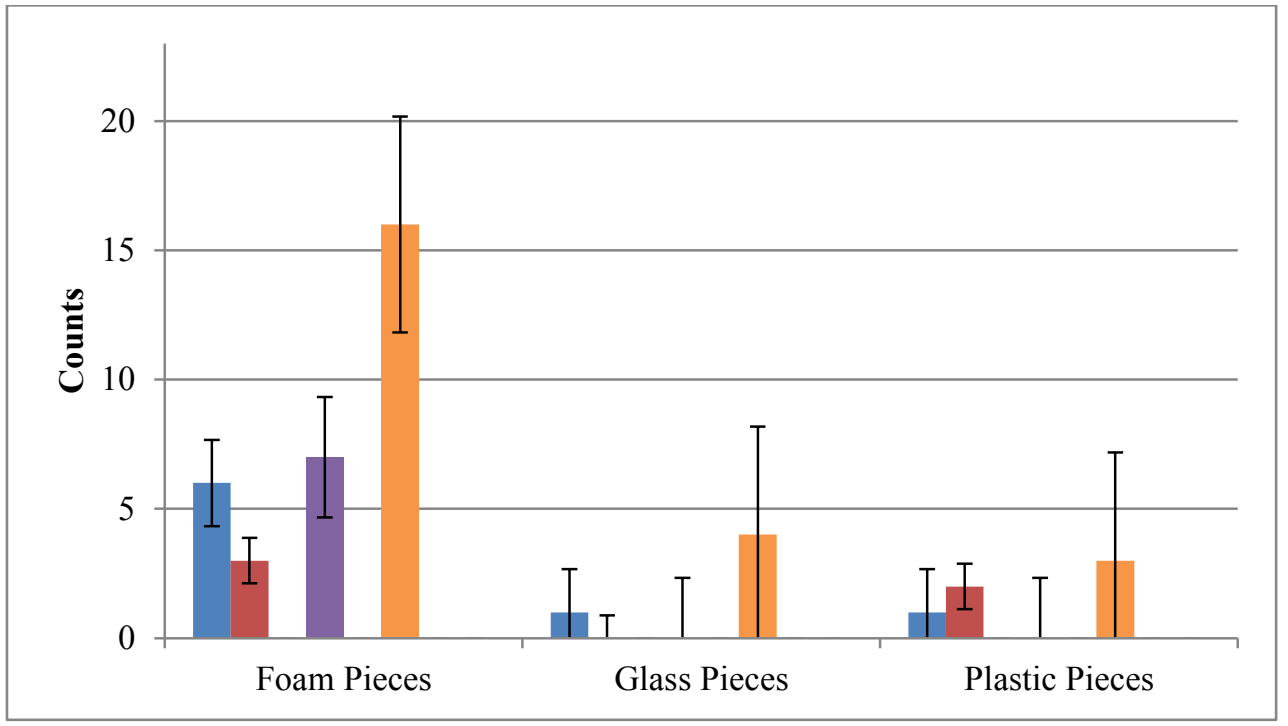

Fig 7. Tiny Trash

Figure 7. shows the tiny trash category chart. Total trash found throughout the station is 42 pieces. The most popular tiny trash category is foam pieces with 32 pieces. Station 6 is a station with the Foam Pieces at most with the amount of garbage found as many as 19 pieces.

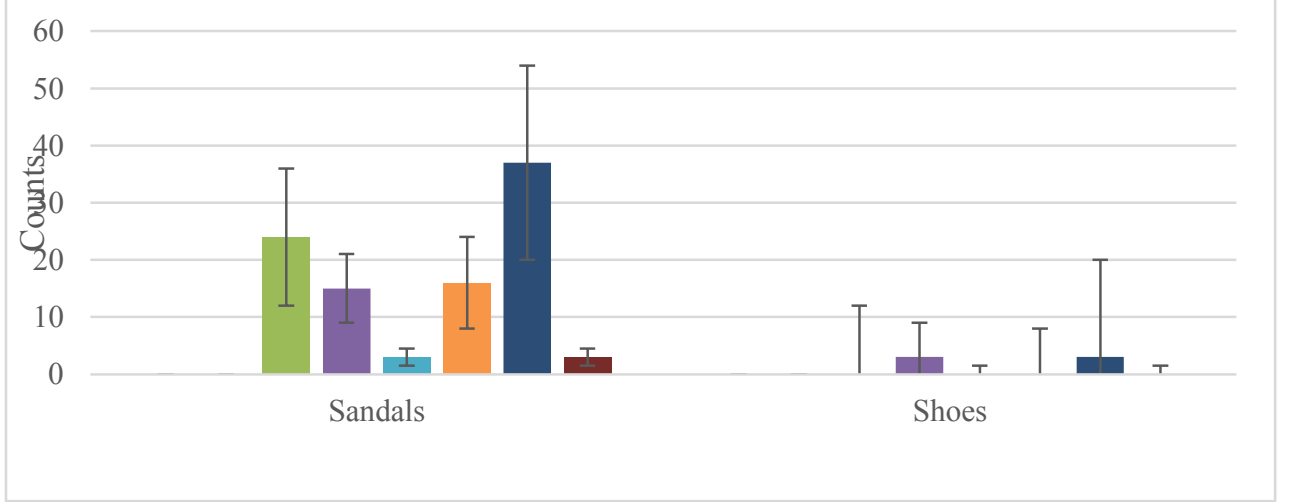

Fig 8. Personal Trash

Figure 8. shows the personal trash graph. The most common type of garbage from this category is sandals with the amount of garbage found in all stations is 98 pieces. Personal Trash category found in station 7 with the number of garbage found 37 pieces. Total trash found in all stations is 104 pieces. This category is an additional category because the garbage is found in most stations but there is no special category in the ICC form. This waste is categorized as Human Trash.

Figure 9 is a visible condition of trash on the coast of the island. Pulau Tunda is one of the islands located in the northern part of Java Sea. The island is adjacent to the Province of Lampung located on the island of Sumatra and Banten Province located in Java. This 
causes the water period in the waters to be affected by two periods of water, the period of water carried from the waters of Sumatra and the waters of Java.
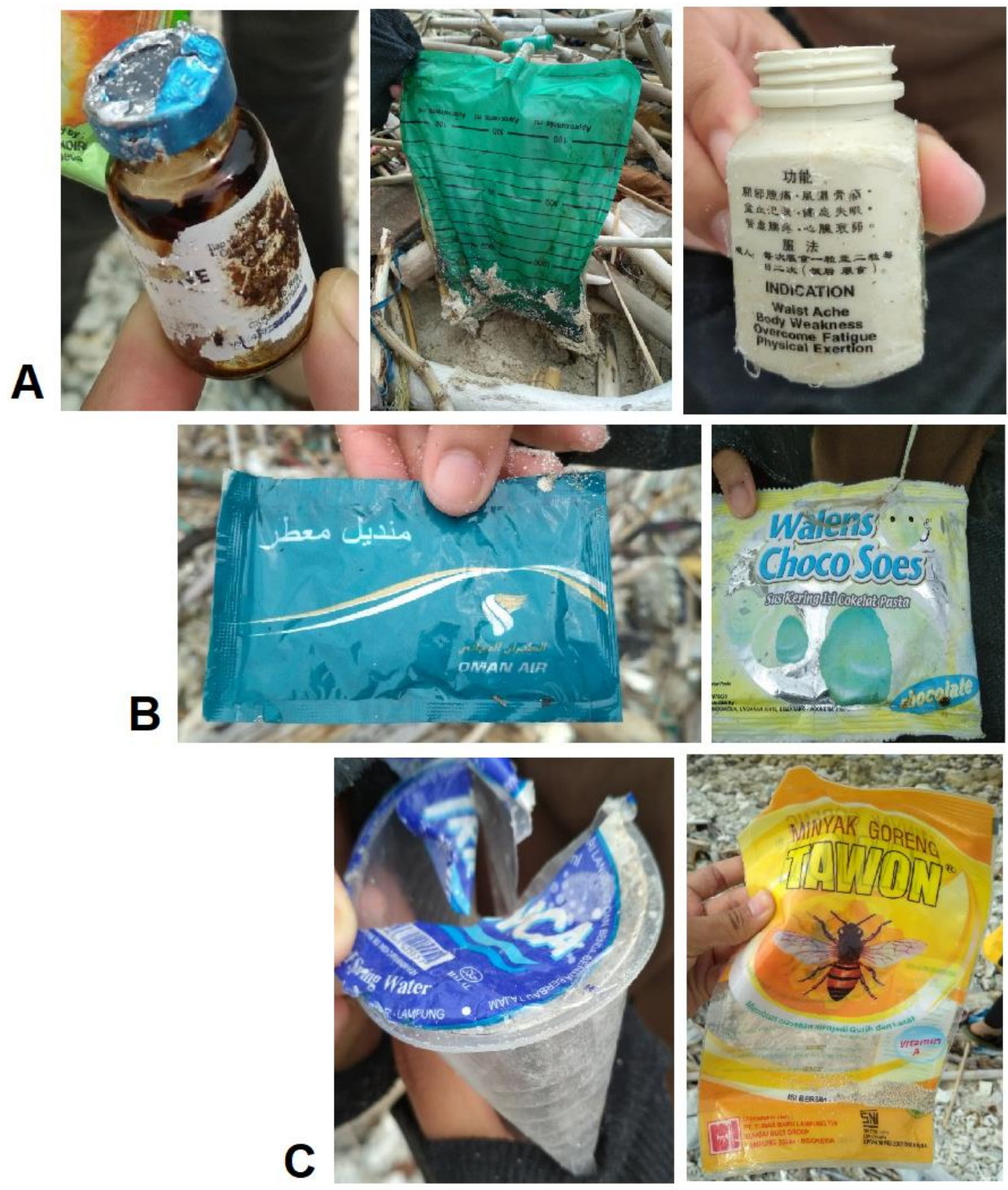

Fig 9. Trash Found in Tunda Island

Marine or marine wastes are known as Marine Debris is mostly about $80 \%$ coming from terrestrial sources. Broadly speaking, marine debris is divided into two types based on the source of the land and from the sea. Trash originating from the mainland and then carried away by rivers, ocean currents, and storms, and waste disposal in the oceans, whether intentional or unintentional is the source of marine debris [22].

According to Greenpeace in 2006, the amount of marine waste that reaches an area greatly relies on ocean currents. Other influencing factors are the distance to the source, debris type (eg resistance), a form of waste (density and size), physical-chemical 
parameters, coastal geomorphology, wind, rain and storm, and tides. There are two factors that influence the distribution of marine debris in the sea, natural and human factors.

Much of the marine debris in the marine environment, particularly in high-populated coastal areas, enter through vast quantities of ship activities, fishing activities, industrial discharges, and river water flow [23,24]. When in the ocean, floating marine debris can be concentrated due to natural processes occurring along the lines of convergence between discrete water masses, at the center of a gyre, or onshore and submerged rock areas where the area is the vital habitat of marine species. For example, water flow along eddies or down welling areas can accumulate floating trash so as to provide food for seabirds and turtles $[24,25]$.

Local-scale phenomena that need to be taken into account in the marine debris movement are the currents (tidal currents and residual currents), wind, rainfall, and natural disasters. Coastal is an area affected by phenomena at sea and landed. So the problem of garbage in the sea and on land will affect the coastal areas.

Tunda Island is a small island located in the Java Sea, north of Banten Bay and separated from the waters of the Thousand Islands, causing the island to be relatively open. The island is located on the western tip of Java Island and adjacent to Lampung Province.

The waters of Banten Bay lie on the main axis of the monsoon wind. In the western period (December - February) the wind in this region is blowing from the west/northwest direction. As for the east wind season (June - August), the wind blows from the east/southeast. This position has consequences for the movement of horizontal water masses (currents) in the region. In the west season the current will move to the east, and in the east season, the current will move west. It is the flow that affects the movement of waste in the sea.

In the east season, the current will move from east to west. So the current will bring a lot of garbage located in the eastern part of Tunda Island, as part of the thousand islands. The waste distribution of the thousand islands is also influenced by the island of Java precisely Jakarta. So it could be the origin of waste that docked in Tunda comes from the island of Java. Besides, Tunda Island is adjacent to Banten Province. So the garbage from Banten province took part in supplying the garbage in Pulau Tunda.

First, the trash comes from the consumption of the residents of Tunda itself, which is thrown away and then drifted by wind or rain to the coast. Both of this garbage come from Lampung Province which carried by ocean currents and anchored in Pulau Tunda. The current carrying the waste is estimated due to the west monsoon. This western wind moves from the west (Sumatra Island) to the East (Java Island). Friction between the wind and the surface of the ocean will cause a current. The direction of the current will follow the wind. So the current will move from west to east. The western part of the island of Tunda is Lampung Province. Therefore, the waste can come from Lampung.

In addition, there is some evidence of waste found not from the island of Tunda. The axis can be seen from Figures 9.1 and 9.2. Figure 9.1 is a medical waste that is infusion and liquid medicine. The waste is usually produced by the hospital. While in Pulau Tunda there is no hospital. Hospitals are listed in big cities such as Banten or Lampung. So it can be ascertained the origin of this garbage is from Java or Sumatra, which is wasted by ocean currents. While picture 11.2 is garbage with foreign language writing. The first picture reads Arabic with Oman Air. The second image of garbage with writing the Chinese language. Both trash is carried by the ocean currents. The current influencing the movement of the waste is very diverse because Indonesian waters are influenced by many world and local currents starting from geostrophic currents, South Khatulistiwa Flow, Java Beach Flow, Aruh Indonesia and Monsoon Flow. So that the movement of sea waste can be waved 
off until finally will be anchored on the coast. Many factors that affect the things mentioned, especially the topography and geography of the beach.

\section{CONCLUSIONS}

It can be concluded that the distribution of garbage in Tunda Island is influenced by some local currents ie currents influenced by east and west monsoon angina. The distribution of waste in this island is influenced by the production of garbage coming from two big provinces namely Lampung and Banten. The two provinces are located on the islands of Sumatra and Java. The most commonly found waste in all stations is food wrappers.

We thanks to Demand Driven Research COREMAP CTI 2018 and PusatPenelitianOseanografi LIPI (021 64713850), its funders and observers for field data collection. We thank to aculty Fisheries and Marine Science UniversitasPadjadjaran, Marine Research Laboratory (MEAL) FPIK UNPAD, Bandung Diving School (SDB) for being safe, supportive and understanding. We also thank to Marine Science UniversitasPadjadjaran Student who has been collected data trough Integrated Research and Community Services Program in 2018.

\section{REFERENCES}

1 D.Ferrol-Schulte, P.Gorris, W. Baitoningsih, D. S.Adhuri, \& S. C.Ferse.Mar Pol, 52, 163-171(2015).

2 N. Rukminasari, Yusran. Jurnal Panrita Abdi.1, (2016)

3 C. Sur, J. M. Abbott, R. Ambo-Rappe, N.Asriani, S. O. Hameed, B. M.Jellison, and S. L. Williams. Frontiers in Marine Science.5, 2 (2018).

4 J. R. Jambeck. Science.347, 768-771(2015)

5 Factsheet. Impact of marine litter.(2012)

6 C. M.Boerger, G. L.Lattin, S. L. Moore, \& C. J. Moore. Mar.Poll. Bull. 60 , 2275 $2278(2010)$

7 V. Hidalgo-Ruz,\& M.Thiel. Mar. Environ.Res 87-88, 12-18 (2013)

8 S. B. Sheavly, Sixth Meeting of the UN Open-ended Informal Consultative Processes on Oceans \& the Law of the Sea. Marine debris - an overview of a critical issue for our oceans. June 6-10, (2005)

9 A. D. Nash. Mar. Poll. Bull. 24, 150-156 (1992)

10 A.McIlgorm, H. F. Campbell, and M. J. Rul.A report to the Asia-Pacific Economic Cooperation Marine Resource Conservation Working Group by the National Marine Science, (Centre University of Coffs Harbour, 2008).

11 CSIRO. Marine Debris: Sources, Distribution And Fate Of Plastic And Other Refuse And Its Impact On Ocean And Coastal Wildlife. Www.Csiro.Au. (2014)

12 B.Glaeser, and M. Glaser .Res.Hum. Ecol. 17, 135-147 (2010)

13 A. R.Farhan, and S. Lim. Ocean Coast. Manag. 54, 391-400 (2011). 
14 S. M. Evans, M. Dawson, J. Day, C. L. J.Frid, M. E. Gill, L. A.Pattisinat.Mar. Poll. Bull. 30, 109-115 (1995)

15 P.Uneputty, S. M. Evans. Mar. Environ. Res. 44, 233-242 (1997)

16 N. G. Willoughby, H.Sangkoyo, B. O.Lakaseru. Mar. Poll. Bull. 34, 469-478 (1997)

17 R. C.Thompson, C. J.Moore, F. S.vom Saal and S. H. Swan. Phil. Trans. R. Soc. B 364,2153-2166(2009)

18 M. R.Gregory Environmental implications of plastic debris in marine settingsentanglement, ingestion, smothering, hangers-on, hitch-hiking and alien invasions. Phil. Trans. R. Soc. B 364, 2013-2025(2009)

19 E. R.Zettler, J. M.Tracy, and, A.Linda. Environ. Sci. Technol.47, 7137-7146(2013)

20 N. P.Zamani.Ilmu Dan TeknologiKelautanTropis 7, 273 - 286 (2015)

21 Lintangkawuryan. AEBMR. 52,(2018)

22 United Nation Environment Program (UNEP). Negative Socio-Cultural Impact For Tourism. Www.Uneptie.Org/Pc/Tourism/Soc-Drabacks.Htm. (2001)

23 T.R.Dixon, and T.J. Dixon. Mar. Pollut. Bull. 12, 289-295 (1981a)12, 53-56 (1981b)

24 D. W.Laist.Mar. Pollut. Bull. 18, 319-326 (1987)

25 A.Car.Rips, FADS, and Little Loggerheads. Bioscience 36, 92-100. 1987.. Mar. Pollut. Bull.18, 352-356 (1986) 